\title{
Samuel L. Hoyt and the Development of Carboloy
}

(c) Springer Science+Business Media New York and ASM International 2016

\section{Editor's Note}

In a recent issue of Advanced Materials and Processes [1], Charles Simcoe's "Metallurgy Lane" feature highlighted the life and career of metallurgist Samuel L. Hoyt. As the article noted, Hoyt documented his professional career in his interesting book Men of Metals [2]. A tagline on the book cover promises the reader will find therein a description of Hoyt's "... exciting career among the trailblazers of modern metallurgy." Indeed, Dr. Hoyt studied under or worked with a number of luminaries in our field, including Henry Marion Howe, Zay Jeffries, Irving Langmuir, and Paul Merica.

Hoyt's career included positions at General Electric, Battelle, and A.O. Smith, as well as a long stint as a consultant to both the government and industry. During his time at General Electric, Hoyt researched tungsten alloys for use as electric lamp filaments. In 1925, Hoyt was sent to Germany by GE to investigate methods underway there of producing aluminum from clay. During his free time, however, he visited European lamp factories to learn about the tungsten wire drawing processes they used. In this fashion, he came to learn about a process developed by the Osram Lamp Works that made use of tungsten carbide dies for drawing the tungsten wire.

Hoyt brought the Osram process back to GE and his work on this topic led to the development of Carboloy and the formation of a company by the same name. Hoyt devotes an entire chapter of his book to Carboloy, not only because it gave birth to the cemented carbide industry in the United States, but also due to the unique patent issues that eventually came into play. The chapter is reproduced here for the benefit of our readers; it is an interesting and important piece of history regarding the development of a critical class of materials.

Interested readers are also directed to the Biographical Memoirs series produced by the National Academy of Sciences. William D. Nix authored a memoir [3] of Zay Jeffries (who worked with Hoyt at GE during this time), which provides a clear, concise summary of the patent issues surrounding Carboloy. Nix's account of Zay Jeffries' career is itself a fascinating story that highlights the critical contributions he made in our field. The NAS biography of Jeffries (and others profiled in this series) is freely available from the National Academy of Sciences website: www.nasonline.org/memoirs.

\section{References}

1. C. Simcoe, Metallurgy lane-pioneers in metals research, Part V. Adv. Mater. Proc. 174(2), 26-27 (2016)

2. S.L. Hoyt, Men of Metals (ASM International, Metals Park, 1979)

3. http://www.nasonline.org/publications/biographical-memoirs/ memoir-pdfs/jeffries-zay.pdf. 